\title{
Art Therapy on the Cognitive Function of Elderly with Dementia
}

\author{
Dewi Murdiyanti Prihatin Putri ${ }^{1}$, Endang Tri Sulistyowati ${ }^{2}$ \\ ${ }^{1}$ Akademi Keperawatan YKY Yogyakarta 55182 Indonesia \\ ${ }^{2}$ Politeknik Kesehatan Karya Husada Yogyakarta 55231 \\ E-mail : dewiputri4377@gmail.com
}

\begin{abstract}
Abstrak
Proses penuaan berlanjut seiring berjalannya waktu dan akan ada penurunan fungsi organ. Penurunan fungsi tubuh yang sering muncul salah satunya adalah penurunan fungsi kognitif. Penurunan fungsi kognitif biasanya berhubungan dengan penurunan belahan kanan otak yang berlangsung lebih cepat daripada yang kiri. Tidak heran bila pada para lansia tenjadi penurunan berupa kemunduran daya ingat visual (misalnya mudah lupa dengan wajah orang), sulit berkonsentrasi, cepat beralih perhatian. Sifat gangguan ini sangat individual, tidak sama tingkatnya seorang dengan yang lain. Kemunduran yang paling dominan ditemui adalah menurunnya kemampuan memori atau daya ingat (Sulianti, 2000). Hal ini seringkali dianggap hal yang biasa dan wajar terjadi pada lansia. Apabila hal ini dibiarkan terjadi maka lansia akan mengalami gejala awal dari demensia yang ditandai dengan banyak lupa. Sebagian besar lansia yang mengalami demensia dengan menunjukkan perubahan perilaku. Penelitian ini bertujuan untuk mengidentifikasi pengaruh terapi seni pada fungsi kognitif lansia dengan demensia dengan desain penelitian ini adalah Quasy Experimental Pre-Post Control Goup Design. Responden dalam penelitian ini berjumlah 82 orang yang dibagi menjadi kelompok kontrol dan kelompok intervensi. Pengukuran fungsi kognitif lansia dengan demensia menggunakan Mini-Mental State Examination (MMSE). Temuan penelitian menunjukkan bahwa ada peningkatan yang signifikan dari fungsi kognitif pada lansia dengan demensia sebelum dan sesudah terapi seni selama 4 (empat) minggu. Pada kelompok intervensi terjadi peningkatan fungsi kognitif sebelum dan sesudah dilakukan art therapy jauh melebihi peningkatan fungsi kognitif yang terjadi pada kelompok kontrol yang dibuktikan adanya selisih rata-rata skor fungsi kognitif antara kelompok kontrol dan kelompok intervensi yaitu sebesar 2,68. Kim (2010) dalam disertasinya mengatakan bahwa art therapy membantu menyeimbangkan kemampuan fisik dan mental lansia karena dapat meningkatkan koordinasi dari gerakan tangan-mata dan bagian lain dari tubuh, modulasi gerakan tubuh dan menyeimbangkan aktivitas antara hemisfer kanan dan kiri dari otak. Rekomendasi dari penelitian ini adalah penerapan terapi seni dapat dilakukan pada lansia.
\end{abstract}

Kata kunci : Terapi Seni, Fungsi Kognitif, Lansia Demensia

\begin{abstract}
The aging process continues as time goes by and there will be an impairment of the organ. Decreased body functions that often appear one of them is a decrease in cognitive function. Decreased cognitive function is usually associated with a decrease in the right hemisphere of the brain that goes faster than the left. Not surprisingly, in the elderly there is a decline in the form of visual memory decline (for example, easy to forget the faces of people), difficulty concentrating, quickly turning attention. The nature of this disorder is very individual, not the same level with one another. The most dominant setback found is decreased memory or memory capacity (Sulianti, 2000). This is often considered normal and natural for older people. If this is allowed to happen then the elderly will experience early symptoms of dementia which are marked by a lot of forgetting. Most of the elderly experienced dementia by showing changes in behavior. This study was to identify the effect of art therapy on cognitive function
\end{abstract}


of the elderly with dementia with the design of this study was Quasy Experimental Pre-Post Control Goup Design. There were 82 respondents divided into control groups and intervention groups. Measurement of cognitive function of the elderly with dementia using the Mini-Mental State Examination (MMSE). The result of the research showed that there was a significant improvement of the cognitive function in elderly with dementia after art therapy for 4 (four) weeks. In the intervention group there was an increase in cognitive function before and after art therapy far exceeding the increase in cognitive function that occurred in the control group as evidenced by the difference in the average cognitive function score between the control group and the intervention group that was 2.68. Kim (2010) said that art therapy is also an activity that increases the coordination of hand and eye movements and other parts of the body as well as increased body movements and simultaneously activity between the right and left brain hemisphere. It can be concluded that art therapy can be applied to increase cognitive function towards the elderly.

Keywords: Art Therapy, Cognitive Function, Elderly with Dementia

Article info:

Article submitted on March 31, 2019

Articles revised on April 29, 2019

Articles received on May 18, 2019

DOI: http://dx.doi.org/10.21927/jnki.2019.7(2).60-67

\section{INTRODUCTION}

The percentage of elderly population that reached over seven percent indicates that Indonesia has begun to enter the group of countries with older structures (Ageing Population Structure). The structure of an aging population is one success indicator of national development achievement, especially as a reflection of the growing average age length of the Indonesian population. The elderly population in Indonesia generally was 18.04 million, or 7.59 percent of the total population. The population of elderly women was 9.75 million, much more than the population of elderly men that was 8.29 million. Viewed from age group, the number of elderly was divided into younger elderly (60-69 years) as many as 10.75 million, the middle elderly (70-79 years) as many as 5.43 million, and older elderly (80 years and over) as much as 1,86 million orang. It is estimated that the elderly population in Indonesia will continue growing around 450,000 per year. Though the number of people in Indonesia during the same period only increase about twice (8).
The aging process continues as time goes by and there will be an impairment of the organ. Decreased body functions that often appear one of them is a decrease in cognitive function. Decreased cognitive function is usually associated with a decrease in the right hemisphere of the brain that goes faster than the left. Not surprisingly, in the elderly there is a decline in the form of visual memory decline (for example, easy to forget the faces of people), difficulty concentrating, quickly turning attention. The nature of this disorder is very individual, not the same level with one another. The most dominant setback found is decreased memory or memory capacity (12). This is often considered normal and natural for older people. If this is allowed to happen then the elderly will experience early symptoms of dementia which are marked by a lot of forgetting. The Indonesian Departement of Health Report in 1998 said that the increase in the incidence of dementia was directly proportional to the increase in the life expectancy of the population. Approximately $5 \%$ of elderly in the age range 
65-70 years with dementia doubled every five years and it reached $45 \%$ at the age above 85 years. Dementia is a collection of symptoms characterized by cognitive and memory disorders and may affect the daily activities. People with Alzheimer's impaired memory and thought process disorder so it affects the ability to make decision. Cognitive function is a human mental process that includes attention perception, thought processes, knowledge and memory. As many as $75 \%$ of the large brain area is a cognitive area (10). Decline in cognitive function experienced by eldery with dementia often affects their daily activities and social interactions. These conditions will also affect the quality of elderly life. Treatments that stimulate cognitive functions are necessary to improve the quality of elderly's life with dementia. Treatment of dementia can be done by pharmacological and nonpharmacological intervention. Pharmacological intervention is conducted by giving medicine that can improve cognitive function, while nonpharmacological interventions include Cognitive Rehabilitation Therapy (CRT) interventions. One of CRT interventions is alternative therapies including art therapy (Art Therapy). Art therapy is a form of therapy by creating an image and playing the image and color object by using objects or art materials to express and reflect on the exercises done (3). Efforts to maintain memory and cognitive abilities in order not to decrease has not done much by researchers. Recently, there is no research on the effects of art therapy towards cognitive function in Indonesia, especially in Yogyakarta. The general objective of the research was to find out the effects of art therapy towards cognitive function of elderly with dementia.

\section{MATERIALS AND METHODS}

The population in this research was all 214 elderly living in the social home of Tresna Wreda. Simple random sampling was used as the sampling techniques. The total sample was 82 consisting of 41 for intervention group and 41 for control group. The inclusion criteria were the $60-90$ years old elderly, suffered a very mild until mild dementia, no alcohol history and no experience of any loss of consciousness. This research used quasy Experiment Pre - Post Control Group Design. The grouping of the sample in the intervention and control groups was conducted randomly or simple randomly. The interventions were art therapy for the intervention group and brain exercise for the control group. Data analysis used univariate and bivariate ways with frequency of chi-square and t-independent and t-dependent test. The research instrument used Mini-Mental State Examination (MMSE) consisting of six parts, namely orientation, registration, attention and Count, Memory, Language, Basic Motoric with the entirely maximum score was 30 (thirty). The instrument interpretation of MMSE towards the elderly cognitive function was conducted before and after the intervention and every week for four weeks. The instrument interpretation of MMSE was: the score of 27-30 points means normal cognitive function, the score of 21-26 points means mild cognitive disorder, score of 11-20 points means moderate cognitive disorder, and the score 0-10 points means severe cognitive disorder. Ethical Clearance conducted by the Committee of Ethics Research Nursing Faculty of Nursing, University of Indonesia. This study was conducted ethical studies to then declared qualified and feasible to do research.

\section{RESULTS AND DISCUSSION Characteristics of the respondents}

All the characteristics of respondent including age, gender, education history, employment history and family support has the categorized form so they were described in the frequency distribution tables. The tables for the respondent's characteristics of intervention group 
and the control group are summarized in a table in order to see the comparison.

Table 1. Distribution of the Elderly with Dementia According to Characteristics of Age, Gender, Education, Employment History, and Family Support

\begin{tabular}{|c|c|c|c|c|}
\hline \multirow[t]{2}{*}{ Characteristics } & \multicolumn{2}{|c|}{$\begin{array}{c}\text { Intervention } \\
\text { Group } \\
(\mathrm{N}=41)\end{array}$} & \multicolumn{2}{|c|}{$\begin{array}{l}\text { Control } \\
\text { Group } \\
(\mathrm{N}=41)\end{array}$} \\
\hline & $F(x)$ & $\%$ & $F(x)$ & $\%$ \\
\hline \multicolumn{5}{|l|}{ Age } \\
\hline $60-69$ & 12 & 29,3 & 13 & 31,7 \\
\hline $70-79$ & 15 & 36,6 & 24 & 58,5 \\
\hline $80-90$ & 14 & 34,1 & 4 & 9,8 \\
\hline \multicolumn{5}{|l|}{ Gender } \\
\hline Female & 27 & 65,9 & 36 & 87,8 \\
\hline Male & 14 & 34,1 & 5 & 12,2 \\
\hline \multicolumn{5}{|l|}{ Education } \\
\hline No Formal Education & 19 & 46,3 & 20 & 48,8 \\
\hline Elementary School & 9 & 22,0 & 10 & 24,4 \\
\hline Junior High School & 4 & 9,8 & 6 & 14,6 \\
\hline Senior High School & 6 & 14,6 & 3 & 7,3 \\
\hline Undergraduate & 3 & 7,3 & 2 & 4,9 \\
\hline \multicolumn{5}{|l|}{ Occupation } \\
\hline Unemployment & 6 & 14,6 & 5 & 12,2 \\
\hline Housemaid & 8 & 19,5 & 9 & 21,95 \\
\hline Labourers & 15 & 36,6 & 9 & 21,95 \\
\hline Government Employee & 2 & 4,9 & 3 & 7,3 \\
\hline Trader/enterpreneur & 5 & 12,2 & 10 & 24,4 \\
\hline Farmer & 3 & 7,3 & 2 & 4,9 \\
\hline Private & 2 & 4,9 & 3 & 7,3 \\
\hline \multicolumn{5}{|l|}{ Family Support } \\
\hline Never & 21 & 51,2 & 13 & 31,7 \\
\hline Seldom (1-2x/year) & 8 & 19,5 & 12 & 29,3 \\
\hline Often (6-12x/year & 12 & 29,3 & 16 & 29,0 \\
\hline
\end{tabular}

Most of the elderly aged $70-79$ was $58.5 \%$ in the control group and $36.6 \%$ in the intervention group, it was supported by the results of the population census (2010) showing that the life expectancy of the elderly increased to average 74 years. It must have been influenced by several factors coming from the inside and the social environment. One of the crucial factors was the elderlys' healthy lifestyle. Most of the respondents were female in the control group as much as $87,8 \%$ and the intervention group as much as $65,9 \%$. This research was also confirmed by a research conducted on elderly people at the social home that used cross sectional method and the sample size of 70 elderly respondents which most of them were female as much as $55.7 \%$. This shows that the elderly who live in social home are mostly female. This was also supported by the results of the population census in 2010 that the life expectancy of women is higher than men (in men 73 years and women 76 years).

A study conducted by survey on the elderly population in Indonesia with the sample of 18.476 elderly showed that most elderly are female which is $70 \%$ of the total sample. This was due to the long life expectancy of elderly women correspond to life expectancy at birth. Women have higher life expectancy at birth than men. Most respondents did not get formal education. It was $48,8 \%$ in control group and $46,3 \%$ in intervention group. It was confirmed by other research using quasy-experiment methods that illustrated the number of elderly who did not attend school were at $40.74 \%$. The awareness of former elderly were still low and it was supported by low education facilities and infrastructure that made many elderly choose not to go to school. Most elderly who ever work were $85,4 \%$ in intervention group and $87,8 \%$ in control group. It was supported by the results of interviews conducted for 10 elderly in social home, it was obtained data that all elderly think that they must work to survive and to meet the individual and family daily needs even with low level of education or uneducated, so most of them worked as housemaids and laborers.

There were $41.5 \%$ of respondents had never received a family visit, Most elderly with dementia do not have family support because those who live in the social home are not married or lonely and they do not have a family and even some elderly are neglected and submitted by the Social Welfare of Yogyakarta. This is supported by a research saying that not all the elderly can enjoy the warmth of a family for the elderly should be away from children and relatives in a nursing home. 
The differences of cognitive function in the control group and the intervention group

The cognitive function in the control group or the intervention group before the intervention is equal or balanced. This is evidenced by the results of equality testing or homogeneity tests of cognitive function before the intervention that showed both groups had the same degree of equality with a $\mathrm{P}$ value $=0.93$ or in other words, both groups were homogeneous. The two social homes have the same daily activities.

Table 2. The Differences of Cognitive Function Improvement

\begin{tabular}{lcccc}
\hline Group & $\mathrm{p}$-Value & Mean & $\mathrm{N}$ & M.Diff \\
\hline Control & & & & \\
$\quad$ Before & 0,003 & 21,56 & 41 & $-0,46$ \\
$\quad$ After & & 22,02 & 41 & $(-0,76 ;-0,16)$ \\
$\begin{array}{l}\text { Intervention } \\
\quad \text { Before }\end{array}$ & 0,000 & 21,66 & 41 & $-3,15$ \\
$\quad$ After & & 24,80 & 41 & $(-3,56 ;-2,74)$ \\
\hline
\end{tabular}

Based on the above table showed that the control group before the brain exercise given the average score of cognitive function of 21.56. After giving brain exercise during the fourth week, the average score of cognitive function was 22,02 . This shows that in the control group after testing using $t$-dependent test there is a significant increase with the value of $p=0.003$ with an average increase of 0.46 points. While in the intervention group obtained the average data of cognitive function score before given art therapy of 21.66 and after given art therapy average cognitive function score of 24.80 . From the test result by using t-dependent test got significant result. The improvement of cognitive function score in the intervention group was 3.15 points. All the results of the tests showed that the average increase in cognitive function in the intervention group $(p=0.000)$ was significantly higher than that of the control group $(p=0.003)$.

The results of the research analysis showed that in the control group the mean of cognitive function score before and after the daily elderly gymnastics for 4 (four) weeks showed a significant cognitive function improvement, it was 0.46 . Similarly in the intervention group, the cognitive funtion showed a significant increase with an average score increase 3.15 after the art therapy. This suggests that the increase in the intervention group is much greater than that of the control group.

Table 3. The Differences of Cognitive Function Improvement of Pre-Post Intervention

\begin{tabular}{lcccc}
\hline \multicolumn{1}{c}{ Group } & Diff & $\mathrm{N}$ & M.Diff & $\mathrm{p}$-Value \\
\hline Control & 0,46 & 41 & $-2,68$ & \\
Intervention & 3,15 & 41 & $(-3,18 ;-2,18)$ & 0,000 \\
\hline
\end{tabular}

Based on the table, the differences between control groups before and after being given elderly gymnastics and intervention groups before and after art therapy were also apparent. In the control group there was difference of mean score of cognitive function before and after giving elderly gymnastics 0,46 with and in intervention group there was difference of mean score of cognitive function before and after giving art therapy 3,15 . The difference between the average difference of cognitive function in the control group and the intervention group was 2.68. After testing by using t-independent test results obtained a significant difference with the value of $p=0.000$. This showed that the improvement of the cognitive function in the intervention group before and after the art therapy was far exceeds the improvement of one in the in the control group. The data was supported by a statement saying that Cognitive Training such as art therapy is very useful to overcome the cognitive function disorders when it coupled with the cognitive stimulation techniques and psychotherapy such as art therapy.

All of the table show that the results of the test using the t-independent test showed that there was a significant difference in the improvement of cognitive function between the control group and the intervention group after 
intervention or before and after the intervention. The elderly of the intervention group with dementia was given art therapy twice a week for 4 (four) weeks. The elderly was asked to draw and color the picture then they discuss with the group about their work. Each meeting was held for approximately 3 hours. After the intervention, there was increasing significant cognitive function in the intervention group after the art therapy. The interventions of art therapy can be performed by art therapists as well as by specialist nurses. Art Therapy can be done in several ways including by providing a colored material and asked the elderly to create a form for example a triangle, a square or a circle. It can also be done by asking the elderly to color a sketch or asking them to draw then color it. Art therapy that is performed simultaneously can deliver a result or improved the cognitive function of elderly people with dementia.

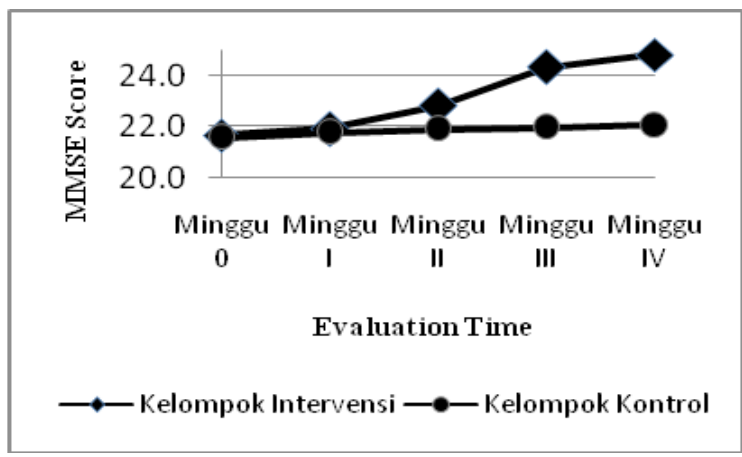

Figure.1. A chart of The Cognitive Funtion Score Evaluation of the elderly with Dementia

Based on the graph above it can be seen that in the week before art therapy averaged the score of cognitive function in the control group of 21.56 and the mean score of cognitive function in the intervention group 21.66. In the first week after art therapy have begun to show an increase in the average score of cognitive function, in the control group the average score of cognitive function was 21.76 and the mean score of cognitive function on intervention group of 21.90. In the second week there was a difference in average increase in cognitive function score, in the control group the mean score of cognitive function was 21.88 and in the intervention group of 22.80 . In the third week the average cognitive function score in the control group was 21.95 and in the intervention group the mean score of cognitive function was 24.29 . In the fourth week the cognitive function score in the control group averaged 22.02 and the mean score of cognitive function in the intervention group was 24.80 . The data and graphic exposures indicates that the average increase in cognitive function of elderly with dementia in the intervention group was higher than the control group.

The difference in the mean scores of the cognitive function in the elderly with dementia occurring in the intervention group is due to the benefits of art therapy is an activity that stimulates brain activity. In addition, every art therapy activities begins with a quiz or questions related to the orientation of both time and place. The intervention of Art Therapy by drawing is also an activity that improves hand coordination and eyes movement and other parts of the body as well as increased body movement and concurrent activity between the right and left hemisphere of the brain. Kim (2010) said that art therapy is also an activity that increases the coordination of hand and eye movements and other parts of the body as well as increased body movements and simultaneously activity between the right and left brain hemisphere. Research conducted by a case study method in Sydney, Australia provides art therapy interventions in groups to the elderly aged 82 years as many as 6 meetings, and each meeting lasted for about one to two hours. Art therapy interventions can be done by art therapist or specialist nurse.

In the control group, it was found a significant increase in cognitive function after being given elderly gym every day for four weeks. The increased cognitive ability is also supported by the statement saying that the decrease in the intensity and the duration of activity will 
accelerate the process of cognitive function decline. To prevent the occurrence of cognitive function decline, it is required physical activity conducted regularly and routinely. The increasing cognitive function experienced by the control group is consistent with the statement saying that physical activity can activate a number of factors that ultimately lead to neurogenesis by increasing the activation of neurons. Routine and regular physical activity is also given to the control group by giving elderly gym every day. Therefore there was an increase in cognitive function after the elderly gym. Increasing the value of cognitive function in the control group was due to the elderly in their daily activities not only get the elderly gym but also they get other activities such as skill guidance, psychological guidance, spiritual guidance, music playing, singing and dancing. These activities can also stimulate the cognitive function of the elderly. From the analysis result of this research, it was found that the increase of the mean score of cognitive function of intervention group is higher than one of the control group.

Although both groups experienced a significant improvement and the average score improvement of the intervention group was higher than one of the control group, the improvement in the intervention group clinically had not been able to increase to the next level or to the higher level. This was due to art therapy was given for 4 (four) weeks which is the initial time of neurons adaptation to physical activity that reaches the deadline of 6 (six) weeks.

\section{CONCLUSION AND RECOMMENDATION}

The characteristics of elderly with dementia are ranged at age of $70-79$ years $(36,6 \%)$ and the majority are female $(65,9 \%)$ in the intervention group, while in the control group are mostly aged $70-79$ years $(58,5 \%)$ and about $87,8 \%$ of them are female. There was a significant improvement in cognitive function in the elderly with dementia before and after art therapy for 4 (four) weeks in the intervention group and in the control group before and after the elderly gym. The cognitive function improvement in the intervention group pre-post art therapy was higher than the one in the control group with the difference of 2.68 points. Recommendation of this research to implement the Art Therapy for elderly not only for those who experience dementia but also for other elderly brain condition.

\section{REFERENCES}

1. Badan Pusat Statistik. (2009). Statistik Penduduk Lansia 2009. Jakarta : Penerbit Badan Pusat Statistik.

2. Crum, R.M., Anthony, J.C., Basset, S.S., \& Folstein, M.F. (1993). Population-Based Norms For Mini Mental State Examination by Age and Educational Level; Journal of American Medical Association, 29 (18). P. 2389.

3. Edwards, D. (2004). Art Therapy ; Creative Therapies in Practice. London : SAGE Publications Ltd

4. Gelder, B. M. (2004). Physical Activity in Relation to Cognitive Decline in Elderlymen. The Journal of Neurology; 63: 2316 - 2321

5. Kim, S., K. (2010). Healthy Aging and Art Therapy. Disertasi. Lesley University. Proquest Data Base.

6. Kurlowicz, L., \& Wallace, M. (1999). The Mini Mental State Examination. Journal Geriatric Nursing, 3 (1):10 - 11

7. Palestin, B., Nurrachmah, E., \& Ariawan, I. (2006). Pengaruh Umur, Depresi dan Demensia terhadap disabilitas Fungsional lansia di PSTW Abiyoso dan PSTW Budi Dharma Provinsi D.I Yogyakarta (Adaptasi Model Neuman), Fakultas IImu Keperawatan Universitas Indonesia.

8. Peisah, C., Lawrence, G., \& Reutens, S. (2011). Case Report : Creative Solution for severe dementia with BPSD: a case of Art 
Therapy used in a patient and residential care setting. School of Psychiatriy, University of New South Wales, Sydney, Australia.

9. Rustika \& Riyadina, W. (2000). Profil Penduduk Lanjut Usia di Indonesia. Jakarta http://ejournal.litbang.depkes.go.id/indexphp/MPK/article.

10. Saladin, K. S. (2007). Anatomy \& Physiology: The Unity of Form and Function 4th Edition. New York : McGraw-Hill Companies inc:513561.

11. Sensus Penduduk, (2010). Statistik Penduduk Lanjut Usia Indonesia 2010 ; Hasil Sensus
Penduduk 2010. Katalog BPS 4104061 Jakarta : Badan Pusat Statistik

12. Sulianti, A., T., T. (2000). Pemanfaatan Momen 17-Agustusan Sebagai Sarana Latihan Olahraga Rekreasi Terapeutik Untuk Lansia. Available from : URL: http://www.koni.or.id/ files/documents/journal/2

13. Tsolaki, et al. (2009). Effectiveness of Non Pharmacological Approaches in Patients with Mild Cognitive Impairment. Original Paper Neurodegenerative Dis ;8; 138 - 145,. Karger AG, Basel. Proquest Data Base. 